\title{
Bosnien:
}

\section{En fejlslagen stat i Europa?}

\section{Vibeke Sperling}

\section{Bosnien må hjælpes ud af det strukturelle mare-}

ridt fra Dayton, hvis det skal blive til mere end en virtuel stat. Men der var både fremskridt og tilbageskridt for integrationsprocessen ved de mange valg i oktober

15 år efter krigens afslutning i Bosnien-Hercegovina styrkede et utal af valg her i oktober 2010 opfattelsen af, at det er en fejlslagen stat midt i Europa. I den kategori regnes normalt fattige lande uden et fungerende statsapparat som Haiti og flere afrikanske stater. Bosnien har derimod modtaget langt over 80 milliarder kroner i international hjælp og fået en overflod af demokratisk valgte magtinstitutioner, der dog modarbejder hinanden. Og ikke mindst fordi magtinstitutionerne er så talrige, deler Bosnien skæbne med flere af de åbenlyst fejlslagne stater, når det gælder korruptionsplage.

Bosnien er det mest skrøbelige af de seks lande, som kom ud af Jugoslaviens sammenbrud og det af lan- dene, som nu er længst væk fra medlemskab af EU. En kunstig stat blev presset ned over bosnierne af det internationale samfund med Dayton-aftalen i 1995. Dayton afsluttede 40 måneders krig, men fastfrøs Bosnien som etnisk delt imellem serbere, kroater og bosniakker (muslimer). Med en fælles føderation imellem de to sidstnævnte og Republika Srpska for serberne var de fælles magtorganer på forhånd gjort magtesløse.

Det centrale mål i Dayton var heller ikke at skabe en fungerende stat, men at få de etniske grupper til at holde op med at slagte hinanden. Det lykkedes. De holdt op, men er fastlåste $\mathrm{i}$ et strukturelt mareridt, der har vist sig at forhindre både demokratisk og økonomisk udvikling. 
Tocifrede væksttal i de euforiske år lige efter krigen blev afløst af stagnation. Og investorer trak sig ud, da der skulle et utal af langsommelige godkendelser til projekter og lige så mange gange bestikkelse.

I november 1995 blev Bosniens, Serbiens og Kroatiens ledere mere eller mindre tvunget til at underskrive en aftale, der afsluttede krigen fra 1992 til 95 og bandt de tre nationaliteter sammen i en særlig forfatningsmæssig uorden. Med kun mindre problemer og ingen ofre blandt Natos styrker blev en sikkerhedsstruktur bragt på plads uden forsinkelse. Og det er en stor succes, at der ikke har været nogen åbenlys fare for genopblussen af krig siden.

\section{5 præsidenter, 150 ministre}

Dayton fredsaftalen overgik i starten alle forventninger for siden at skuffe fælt, ikke mindst på grund af de mange og modsatrettede magtinstitutioner.

Ud over de to etniske enheder blev Føderationen inddelt i ti kantoner. Det kom til at betyde i alt 14 regeringer, 14 regeringsledere, fem præsidenter og over 150 ministre, mange med overlappende myndighed. Der er omkring 70.000 til at administrere på de forskellige niveauer i landet med 4,8 millioner indbyggere. Administrationerne sluger næsten halvdelen af Bosniens statsbudget. Altså et rasende dyrt og ineffektivt politiske rod.
Visse fremskridt for integrationen imellem de etniske grupper er dog sket. Efter krigen havde landet tre hære, tre efterretningstjenester, tre politistyrker, to centralbanker og to valutaer.

Nu er der én hær, mens der stadig er meget tilbage at ønske for sammenlægning af politistyrkerne. $\mathrm{Og}$ nu er der kun en valuta, den konvertible mark, der er bundet til euroen, selv om den serbiske dinar kan bruges i Republika Srpska. De kompromiser, der ellers er indgået, tager imidlertid primært sigte på at forhindre, at en af 'de andre' får mere at skulle have sagt i konfliktløsninger. Resultatet er ikke overraskende politisk lammelse.

Med den reelle magt i hænderne på etniske partier og politikere har nationalistisk retorik traditionelt været en større stemmesluger end forhandlings- og kompromisvilje. Det har været repræsentanter for de tre parter, som startede krigen, der siden har bestemt slagets gang.

\section{Nationalisme styrket og svækket}

Det billede ændredes noget med valgene 3. oktober i år, der bragte både fremskridt og tilbageslag. Den gode nyhed var, at i Føderationen blev Socialdemokratiet, der har brudt med efterkrigstidens nationalistiske dominans, markant styrket. Den dårlige nyhed, at ved valgene $\mathrm{i}$ Republika Srpska og til de fælles magtorganer blev nationalisterne 
blanddt serberne markant styrket.

Milorad Dodik vandt stort ved den serbiske enheds præsidentvalg, efter at han under valgkampen havde skruet op for truslerne om at udråbe Republika Srpska som et selvstændigt land. Blandt hans slagkraftige paroler var, at serberne tilsidesættes både af Bosniens centralregering og af det international samfund, og at Republika Srpska har lige så stor ret til selvstændighed som Kosova.

Analyser af resultaterne viser, at muslimer i stort tal krydsede etniske linjer og favoriserede kandidater, der argumenterede bedst for en multietnisk fælles stat.

Kroaternes stemmer var splittede. Mange fulgte nationalisten Dragan Covics parti, der kræver, at kroaterne får en autonom enhed lige som serberne. Men valgt til det kollektive præsidentskab for kroaterne blev den moderate kroat Zeljko Komsic, der er varm fortaler for en multietnisk stat. Men nationalisten Covic talte om 'valgsvindel', da han mente, at muslimer og ikke kroater sikrede Komsic kroaternes præsidentpost.

Serbernes mand i præsidentskabet, Nebojsa Radmanovic, støtter Dodik, så også valget af Radmanovic styrkede den serbiske nationalisme på centralt plan. Bosniakkernes plads i præsidentskabet gik som kroaternes til en moderat, Bakir Izetbegovic. Han er søn af Alija Izetbegovic, bosniakkernes tidligere leder, der underskrev Dayton. Bakir er mere moderat end både faderen $\mathrm{og}$ sin farligste udfordrer ved valget, Haris Silajdzic.

Den stadig stærkere støtte blandt de bosniske serbere til et helt selvstændigt Republika Srpska har øget de etniske spændinger i de seneste år og betød en ekstraordinært bitter valgkamp.

\section{Andres skyld}

Svar på spørgsmålet om, hvis skyld det er, at Bosnien ikke hænger sammen som stat, afhænger af svarerens nationalitet. Bosnierne peger i større eller mindre grad på Dayton.

Bosniens største etniske gruppe, bosniakkerne (48 pct.), giver som regel Dayton hele skylden, fordi aftalen fastfrøs en etnisk deling, der gjorde fælles beslutninger stort set umulige. Serberne (37 pct.) er en del mere tilfredse, da aftalen gav dem stor autonomi, som de siden i strid med fælles love har styrket for Republika Srpska.

Serberne anklager imidlertid Vesten for at undergrave Dayton med forslag om en ny forfatning med overdragelse af beføjelser fra enhederne til centralregeringen. Bosniskserbiske ledere har kaldt Dayton 'vores bibel'. De mener, at bosniakkerne vil tage magten ved at gøre Bosnien til en enhedsstat, hvor hver indbygger har en stemme, så de og kroaterne reduceres til magtesløse mindretal. Serberne hævder, at bosniakkerne vil udnytte Vestens for- 
kærlighed for en fælles stat til at skabe en islamisk stat i Europa.

Det er en af de mange ødelæggende myter, da bosniakkernes store flertal er europæiske muslimer, der tror på demokrati.

Kroaterne(14 pct.) er et stykke ad vejen enige med serberne, men er slet ikke så glade for Dayton som dem. De mener, at Dayton er en unfair aftale, fordi den henviste dem til en føderation med bosniakkerne. Kroaterne mener ikke, at de ti kantoner i Føderationen retter op på det, selv om der er kroatisk styre i kantoner med kroatisk flertal.

Dayton anklages ofte uretmæssigt for nærmest at have skabt den etniske splittelse, selv om den var selve krigens drivkraft. Hensigten bag Dayton var at tæmme splittelserne, som havde betydet diskrimination, krig og etnisk udrensning.

\section{Ikke opfundet i Dayton}

Bosniens to enheder blev heller ikke opfundet i Dayton; den bosniakkiskkroatiske Føderation blev dannet i 1994 og Republika Srpska i starten af krigen. Ud over at standse krigen handlede Dayton om at drage interne grænser og normalisere relationerne imellem de tre folk. Det sidste vakte langt færre følelser, og det første slugte al energi.

Men hvad skete egentlig i Dayton? Udgangspunktet var en 51:49 deling af det bosniske territorium imellem Føderationen og Republika Srpska.
Baggrunden var et løfte, som USA havde givet Serbiens daværende præsident, Slobodan Milosevic, der til gengæld lovede at få Bosniens serbere til at acceptere en aftale på det grundlag. Bosniens serbere mente derimod, at 70 procent af territoriet historisk tilhørte dem. Milosevic tog aldrig afstand fra sådanne ekstremistiske mål, men hævdede over for internationale forhandlere, at det var fair at give serberne knap halvdelen af territoriet.

I Dayton var Milosevic tydeligt desperat for at få en aftale på plads, så Serbien kunne blive af med de ødelæggende sanktioner. I en forhandlingsrunde med bosniakken Haris Silajdzic erklærede Milosevic sig enig i, at næsten hele hovedstaden Sarajevo, hvor den største enkelte koncentration af serbere boede før krigen, skulle tilhøre bosniakkerne. "Jeg var forbløffet, for han gav i realiteten Sarajevo væk på det tidspunkt" skriver den amerikanske mægler Chris Hill i sine erindringer om forløbet.

De bosniske ledere, Alija Izetbegovic og Haris Silajdzic, var i det store hele tilfredse med måden, hvorpå skillelinjerne blev tegnet. De fik kontrol med tre af de fem store byer (Sarajevo, Tuzla, og Zenica), delte kontrollen over Mostar med kroaterne, mens Banja Luka var den eneste store by, der kom under serbisk kontrol.

Før forhandlingerne havde Milosevic tvunget de bosniske serbere til 
at skrive under på, at han havde det endelige ord at skulle have sagt $\mathrm{i}$ Dayton. De bosnisk serbiske ledere ville ikke skrive under på Dayton, som imidlertid blev sat i værk ret gnidningsløst, fordi de bosnisk serbiske sikkerhedsstrukturer var kontrolleret af Beograd.

Indvendinger fra bosniske kroater blev også tilsidesat af deres oprindelseslands præsident, Franjo Tudjman, der frydede sig over at have 'løst det serbiske spørgsmål' i Kroatien med indtagelse af Krajina, hvor serberne havde været i flertal siden $\emptyset_{\text {strig- }}$ Ungarns dage. Omkring 150.000 civile serbere blev etnisk udrenset under 'Operation Storm' få måneder før Dayton, og Tudjman kunne dårligt få armene ned i begejstringen over Kroatiens generobring af Krajina.

Krajina havde erklæret sig selvstændigt, tilskyndet af Tudjmans parole: 'Kroatien for kroater'. Tudjmans opfattelse af Føderationen var, at kroaterne ville få størst indflydelse, selv om de var i mindretal. Men de var meget smartere end bosniakkerne, der ville være afhængige af de bosniske kroater og Kroatien i al evighed, troede Tudjman.

\section{Nyt forsøg}

Det er nyttigt at genkalde sig historien om vejen til Dayton nu, hvor nye forsøg på at reformere Dayton ventes med henblik på at give landet stærke statsstrukturer og en stærk national ledelse, især til at repræsentere landet internationalt og primært i processen for EU-integration.

Geografien har placeret Bosnien i Europas udkant. Krigen rykkede det ind i kontinentets hjerte, men her 15 år efter Dayton lider Bosnien under et blegnet internationalt engagement, tilsyneladende mangel på retning fra EU og et tydeligt skifte i USA's prioriteringer. Det har efterladt et politisk tomrum, der er åbent for lokale separatister og lyssky udenlandsk indblanding.

Lange og frustrerende forhandlinger, ledet af EU og USA, om forfatningsændringer til fordel for en slanket administration på alle niveauer og en stærkere centralregering måtte tidligere på året opgives, primært på grund af serbisk modstand. Diskussioner med bosniske ledere om, hvordan den forkrøblede stat kunne bringes til at fungere, blev lagt på is i håb om nye tider efter oktobervalgene.

Et af hovedargumenterne i 1990'erne var, at det 'internationale samfund' havde pligt til at gribe ind for at redde en 'multikulturel' regering i Sarajevo fra de etnisk ekskluderende serbere og kroater.

Den serbiske kommentator Nebojsa Malic ser sådan på det: "Det var en myte; regimet i Sarajevo var overvejende muslimsk. Men det var en myte, som var i USA's kram, og myten blev indbygget i Dayton fredsaftalen. Selv om Bosnien var historisk hjemsted for ortodokse, katolske 
kristne, muslimer og jøder, levede de aldrig sammen, kun side om side. De begyndte først at blandes i det sekulære socialistiske Jugoslavien efter Anden Verdenskrig".

Og det er baggrunden for, at ekstraordinært mange i Bosnien så og ser sig som jugoslavere med den bedste del af deres liv i Titos Jugoslavien

Forfatteren og kommentatoren Muhrem Bazdulj skrev i Sarajevo dagbladet Oslobodenje, at samfundene i Bosnien før konflikten i 1990'erne "havde deres forskelle, men de var i realiteten forbløffende monokulturelle: De talte det som de anså for at være det samme sprog, og var ikke segregerede".

Hvis multikulturalisme betyder parallelle ghettoer, så er Bosnien ifølge Bazdulj i dag i sandhed multikulturelt. Folk bor side om side, men ikke særligt lykkeligt. "Af alle de moderne 'multi'er' er kun multivitaminer tilbage”, skrev Bazdulj.

\section{Bosnien som laboratorium}

EU's leder, Herman van Rompuy, drog før valgene til Sarajevo for at belære bosniske politikere om behovet for reformer. Bosnien må blive "et land, der taler med en stemme", før det kan lukkes ind i EU og NATO. Men er sådan et Bosnien muligt?

Muhrem Bazdulj skrev: "Bosnien har været et laboratorium for statsopbyggere, interventionister, huma- nitære hjælpere og aktivister fra hele verden. De har afprøvet alle deres kæreste dogmer og ideologier, fra stammedemokrati til multikulturalisme og velfærdsstat. Alt er slået fejl. I dag er Bosnien delt som aldrig før med omfattende fattigdom og kriminalitet, og tusinder betaler for at besøge healeren Mekki Tourabi, efter at have udtømt alle andre veje til at forbedre deres liv".

William Montgomery, USA's tidligere ambassadør i Serbien og Kroatien og Barack Obamas rådgiver for Balkan, er blandt dem, som ser Bosnien-Hercegovina som fejlslagen stat. Og Montgomery drager en særlig konsekvens. I et tv-interview sagde Montgomery i eftersommeren, at det er en stat, hvor intet virker og en løsning kan være 'fredelig opløsning af landet'.

Det er dog en ide, som ingen amerikansk præsident har støttet. Montgomery sagde, at intet kan løses på statsligt niveau trods 15 års store internationale anstrengelser. Han sagde, at ingen skal tvinges til at blive i et land, som ikke fungerer, og at alt vil være fint, hvis Republika Srpska tillades at forlade Bosnien. Han mener, at hverken serbere eller kroater føler, at Bosnien er deres land.

Montgomery anklagede bosnierne for 'at leve i fortiden', og han blev anklaget i bosniske medier for at være 'lobbyist for serberne'.

Face TVbesøgte den lille enklave Posavina, der er en af føderationens 
ti kantoner. Den er omgivet og delt af Republika Srpska territorium. Her er kroater i flertal, og de fleste menes at støtte etableringen af en tredje kroatisk enhed.

Den lokale politiker Ninoslav Susilovic sagde dog skeptisk: "Hvis vi får en tredje enhed, vil det betyde, at serberne vil ende op ved Una (grænseflod mellem Bosnien og Kroatien), og vi vil få en islamisk stat $\mathrm{i}$ hjertet af Europa, og det vil intet godt medføre".

Præsten Marijan Zivkovic sagde: "Vi prøver stadig at skabe os selv, men vi er endnu ude af stand til netop det". Han mener, at alle tre etniske grupper prøver at udarbejde deres egen strategi for livet med de andre, men at lokale politiske ledere ikke er parate til at opgive deres politik fra 1990'erne.

\section{Danmarks fejlgreb}

Det er især EU-landes ansvar at hjælpe Bosnien ud af dødvandet. Men hvad gør Danmark? Lukker sin ambassade i Sarajevo i 2011. Det er ufattelig dumt, ikke mindst fordi Danmarks stjerne er så relativt høj blandt bosnierne, at lydhørheden over for danske politikere og eksperter er stor. Det er yderligere beklageligt, fordi Danmark i Kirsten Geelan har en fremragende ambassadør i Sarajevo

Udenrigsministeriet argumenterer med, at vi ikke har samme behov som tidligere for at være der, da
Danmark på grund af forsvarsforbeholdet ikke længere har styrker i landet. Men hvad med bosnierne? En udbygning af EU's tilstedeværelse kaldes en erstatning, men der er ikke brug for et større EU-bureaukrati i Bosnien. EU-lande må engagere sig meget mere enkeltvis og blive.

EU's særlige ansvar er primært at fremme Bosniens regionale sammenhæng.

Kroatien står på EU's dørtrin, men det bør være en af betingelserne for fremskridt i den proces, at Kroatien påvirker Bosniens kroater til forsoning og samarbejde. Serbien er kommet nærmere EU, men må gøre sin indflydelse gældende over for Bosniens serbere. EU bør klart fortælle de to lande, at status quo i Bosnien forsinker medlemskab for dem.

Problemet kan ses i sammenhæng med almene tendenser til fragmentering og regionalisering i Europa. Belgien kan eksempelvis næppe kaldes en stat, der hænger sammen. Men der er dog meget stor forskel fra en stat skabt af etnisk udrensning, hvor titusinder stadig venter på at vende hjem.

EU bør snarest enes om en køreplan, som kan bringe Bosnien ud af Dayton-aftalens absurditeter.

Zilka Spahic-Siljak, advokat, muslimsk feminist og vicedirektør ved tværfaglige studier ved Sarajevos Universitet, siger, at EU og USA efter Dayton svigtede de forpligtelser, 
som "de havde efter at havde påtvunget os varig etnisk deling".

Det er de to parters pligt nu at hjælpe bosnierne ud af den deling, mener hun.

Lige efter valgene i oktober, sagde hun: "Bosnien er en højst unormal stat og vil ende som en helt fejlslagen stat, hvis ikke USA og EU lever op til deres ansvar".

\section{Den Høje Repræsentant}

Blandt de mange grunde til, at Bosnien ikke kan kaldes en stat på egne ben, er at det med Den Høje Repræsentant i Sarajevo fortsat er et internationalt protektorat. Og mange advarer imod de seneste måneders tale om at nedlægge denne repræsentation.

Zilka Spahic-Siljak siger: "Det vil være en katastrofe for landet at gøre det, før vi har en forfatning, der kan få Bosnien til at hænge sammen. Det internationale samfunds såkaldt Høje Repræsentant har i det mindste visse midler til at holde vores etnisk splittede politikere i ørerne".

Hun mener, at Milorad Dodik fortsætter med at blokere for fremskridt for en fælles stat, "så længe det internationale samfund tillader ham at true og afpresse. Og han har desværre mange venner i Europa. Rusland selvfølgelig, men også Frankrig, Storbritannien og andre".

Håbet om, at valgene kunne bane vej for et kompromis, brast. $\mathrm{Og}$ nu kan det blive sværere og dermed yderligere svække Bosniens muligheder for EU-medlemskab.

Både Albanien og Serbien ventes at få status som EU-kandidater i nærmeste fremtid. Det vil efterlade Bosnien som det eneste af Vestbalkans lande, som stadig er meget langt fra start på en medlemsproces.

Det internationale samfunds repræsentant i Sarajevo, Valentin Inzko, gjorde gode miner til slet spil, da han efter valgene udtrykte glæde over den store valgdeltagelse på omkring 56 procent, få procent flere end ved forrige valg i 2006.

Men Inzko måtte erkende, at der sikkert vil gå måneder, inden der kan dannes koalitioner til de forskellige magtorganer, som valget drejede sig om.

Zilka Spahic-Siljak sagde: "Der kommer tidligst koalitioner på plads, når vi er inde i 2011”. Og før de er på plads, kan der ikke gøres nye forsøg i forfatningsprocessen.

\section{På randen af fallit}

Det er ikke kun serberne, som truer den bosniske stat.

"Bosnien kan ikke vare ved, hvis dets største enhed (den bosniakkiskkroatiske Føderation) ikke fungerer eller den mister støtte fra almindelige kroater og serbere", siger Marko Prelec, Den Internationale Krisegruppe ICG's ansvarlige for Balkan.

I mere end et år har regeringen $\mathrm{i}$ Føderationen for bosniakker og kroater været ude af stand til at træffe 
beslutninger på grund af etniske stridigheder. Det har helt bremset reformer. Bosnien er på randen af fallit med stor social uro ifølge ICG, der frygter fornyet etnisk vold. Det hedder i en ny rapport fra ICG: "En velfungerende Føderation kunne stimulere til deltagelse fra bosniske kroater og serbere under forhandlinger med Republika Srpska. En succesrig ændring af statsstrukturerne kan vende udviklingen på statsniveau. På den anden side kan fortsat forværring i forholdet mellem bosniakkiske, kroatiske og serbiske ledere i forbindelse med økonomisk nedsmeltning efter valgene få den folkelige utilfredshed til slå over i etnisk vold".

Zilka Spahic-Siljak mener, at alle tre etniske grupper er så krigstrætte, at der næppe er fare for ny krig, men almindelige borgere ser med en arbejdsløshed på officielt 43 procent ikke lys forude, så alvorlige frustrationer præger dagliglivet. Hun håber, at det internationale samfund igen sætter fokus på Bosnien, inden det går helt galt.

Det er, som kommentatoren Mark Lowen skrev i et 'Postkort fra Sarajevo': “Tegn på fremskridt i nogle lej- re forstyrres af styrket nationalisme i andre. Der er mange især unge bosniere, der ser sig selv som netop bosniere snarere end som serbere, kroater eller bosniakker. De drikker kaffe sammen på Sarajevos smarte cafeer og hujer for det bosniske fodboldhold, snarere end for Serbiens og Kroatiens. Men der er også dem, som lever et rent monoetnisk liv i mistro til 'den anden'. Politikerne har ikke gjort meget for at bringe parterne sammen ved disse valg. Så der er stadig grund til frygt for, at dette lille smukke land kan blive en fejlslagen stat".

Bosniakker, kroater og serbere sidder fast på halvvejen mellem Dayton og Bruxelles, mellem et EU, der er trætte af dem uden at kunne sig det højt, og deres egne lederes mundhuggeri.

EU bærer en meget stor del af ansvaret for at forhindre, at Republika Srpskas præsident, Milorad Dodik, får ret i konstateringen: "BosnienHercegovina er en historisk fejltagelse".

Vibeke Sperling er udlandskorrespondent på Politiken og redaktør af Udenrigs. 